\title{
ACHIEVEMENTS IN TRAINING OF FUTURE TECHNOLOGY TEACHERS: EUROPEAN EXPERIENCE
}

\begin{abstract}
The article discusses the possibilities and prospects of using the experience of training future technology teachers in European countries. Its structure and content in accordance with national traditions and European standards led to the success of the educational components of the European Higher Pedagogical School. This fact encourages local scientists and teachers to identify ways of educational achievements use in European education system of technology teachers training. According to the above, we have defined the following tasks: summarize the progressive trends and approaches to quality training of European teachers of technology in national high school; formulate guidelines that will help improve training efficiency of Ukrainian technology teachers and, consequently, ensure the successful integration of the national educational system to the European Higher Education Area.

Key words: education system, technology teacher, teaching experience, educational process, professional readiness, knowledge integration, integration approach.

\section{INTRODUCTION}

Political, social and economic changes of recent years in Europe have led to a series of reforms and changes in education. As Ukrainian education is on its way to joining to the European Educational Area, there is a need for fundamental change in the entire system of higher education and its significant upgrade. In modern conditions of local education it is important to understand, in what way professional and pedagogical training of teachers shound be changed, including teacher of technology. An important source of definition of modern development strategies in teacher education of Ukraine is to analyze the international experience of training teachers. In addition to technology training, an important part of professionalism is the formation of personality traits such as independence, ability to make decisions, creative approach to profession, skills for lifelong learning, communication skills, ability to cooperate and others. In the laws of Ukraine "On Education", "On Higher Education" and in the "Conceptual Principles for Teacher Education development in Ukraine and its integration into the European Educational Area" such quality requirements are highlighted that should provide personal-professional development of future teachers (Вульфсон, 1999).

Search for a new paradigm of education inevitably leads us to a qualitatively new understanding of the position of technology teacher as the quintessence of the target, essential and procedural characteristics of the study. Therefore humanization of training future technology teachers, essentially, is such value orientation that is based on the alteration of personal attitudes of teachers through the search of frameworks of selfactualization, creativity, integrity and integrative way of thoughts, control over mechanism of development, self-learning and self-education (Капранова, 2004).
\end{abstract}




\section{THE AIM OF THE STUDY}

This paper is aimed to justify recommendations for the implementation of experience of training future technology teachers of European countries in educational practice of Higher Pedagogical Schools in Ukraine.

\section{THEORETICAL FRAMEWORK AND RESEARCH METHODS}

The primary task of educational development is to create a system of teacher education, which on basis of national heritage of world importance and established European traditions ensures the formation of pedagogical workers, able to perform professional activities at high level.

Theoretical analysis of scientific papers showed that to the preparation of future teachers are devoted a large amount of research, both theoretical and practical (N. Abashkina, E. Brazhnyk, A. Dzhurinsky, C. Korsak, N. Leshenko, V. Madzihon, S. Malkov, N. Nychkalo, L. Puhovska, A. Romanovsky, A. Sbruyeva, V. Sidorenko, B. Vulfson and others). Development of education and science was researched by European scientists: A. Alamaki, K. Borg, T. Kananoyya, P. Kansanen, B. Lindberg, L. Lindstrom, B. Magne, J. Peltonen, J. Rasmussen, G. Stanhvik, E. Terhart, H. Thorbjornsson, G. Torsteynsson, M. Yohansson that at various times determined conceptual frameworks of technological education in European countries with the need for further reorganization of the structure and content of education of future technology teachers. The study of scientific achievements, advanced pedagogical experience of European countries allow us to determine the ways of improving the system of training of future technology teachers in Ukraine and to provide a set of major changes, namely in the educational system; personal and professional areas of a future specialist. For the system of training future technology teachers in Ukraine, this means not simple filling with new content all curriculums and insignificant changes, but equal entry and integration into the European Higher Education Area (Marginson, 2008).

During the study, we used the following methods: analysis and synthesis of psychological and pedagogical scientific knowledge, comparison, classification, systematization, generalization.

\section{RESULTS}

In the base of common European educational area development are assigned five strategic tasks aimed at creating a new Europe - Europe multicultural; Europe mobile; Europe, which guarantees to all quality education; Europe skills; Europe open to world (Капранова, 2004).

In most developed European countries in accordance with government policy in education, training of future technology teachers takes an important place among scientific developments aimed at its improvement. Particular relevance for researches provides globalization in the world, the rapid development of new production technologies and public relations. The greatest success in that aspect reached some countries of Europe (Denmark, Iceland, Finland, Norway, Poland, Sweden) that have become the worldwide leaders in technological education development.

The longstanding experience of the system for training future technology teachers, recognized in the world and in Europe, could become the basis for the Ukrainian Higher Pedagogical School in the implementation of European integration's directions. The usage of successful experience of teaching acquired a particular importance in terms of the current global economic crisis, when there is a particular need for highly qualified teachers, who are professionally flexible and competitive on the labor market.

Traditionally, qualified technology teacher training is still an important factor in European society and educational systems in each country and is aimed at the formation of 
a professional with a high social responsibility, and striving for further self-education (Лахотнюк, 2007).

Exploring the training of future technology teachers in educational establishments of Europe, we believe it is important to consider it in the context of general trends in the European Higher Education Area.

For example, according to the Act on Higher Education of Sweden, technology teacher training is related to the research work and is aimed at teachers' future professionalism development. According to the Decree on the Higher Education of Sweden to obtain a qualification a teacher or a student must acquire education degree at university or university college. Main requirements for the qualification of teachers depend on the type of institution in which the future teacher of technology is going to work. Training of both pre-school teachers and technology teachers requires gaining by students at least 140 credit units; primary school teachers - 160 credit units etc. Future teachers of secondary school and senior classes of high school should get 180 units of credit, including the study of one or two subjects they intend to teach. Education is regarded as a communicative act. The prevailing form of study for technology education is discussion during seminars. Professional training of teachers is regarded as the main component of teacher education. Professionalism includes professional knowledge, skills and quality of work, teacher's ability for reflection, ability to bind theory with practice. It takes greater significance for technological approach to the training of teachers. Technologies of training (studentcentered exercises; school-based teacher training; reflective trining planning; problematic training; project activities etc.) are the central directions for technology teachers' training in Sweden (Пуховська, 2010).

Particular trends in the system of technology teacher training in Europe have been identified during the theoretical analysis of the outstanding researchers' works. In our opinion, creative application of these trends in Ukrainian educational environment can result in significant positive changes. They are:

1. Democratization and humanization of the system for technology teachers training. A special requirement for future technology teachers, given the national education policy of European countries is to be professionally prepared for the level of development of modern science and production on democratic principles, to ensure the development of mental and physical abilities of students, respect to human labor.

The function of technology teacher according to this approach is subject to significant change and means transforming towards interaction "teacher-student" in the way of strengthening values and ideals (Вульфсон, 1999).

The basis of the system of relations "teacher - student" in educational systems in Europe is the idea of democracy and cooperative interaction between the educator and student. This approach, which is opposed to that of Ukraine, will change the concept of training teachers to be authoritarian "mentors" rather than organizers of various kinds of activities. For example, in the Swedish program LPO94 it is noted that "education should attempt to adapt to the specific circumstances of each student's needs. This primarily presupposes that for the implementation of competent and systematic leadership during teaching and education, future teachers require professional training directed at the development of pupils' critical thinking, creative skills, aesthetic taste, and love of labor, self-education and self-improvement in the democratic atmosphere. In addition, educational process in a democratic society provides an opportunity for all participants to learn about other cultures and ways of seeing and differentiating the similarities and differences" (Рогачев, 2000). 
2. Integrated organization of future technology teachers training. In the twenty-first century teaching methodology certainly continues to study and creatively introduce the achievements of education in Europe in terms of future technology teachers' training. Providing the integration with the environment, society, human, manufacturing, namely professional activity, optimally "built into" teacher's professional world of manufacturing technologies and traditional values of his own nation, will determine the future of technological education.

3. Combination of national and traditional approaches to technology teacher training with the internationalization of education. At the core of education the culture of each of European countries is always presented, formed in close cooperation of its own original culture with other cultures of Nordic countries and European nations. The training process must take into account the national and local peculiarities, national languages, religious denominations, primordial culture of the titular nation and national minorities (Valimaa, 2004).

4. Practically-oriented character of future technology teachers training and strengthening relations with school (as a future place of work). One of the prominent features of European systems for technology teacher training is practical orientation, which is based on democratic values with a specific task to form the willingness for future teachers to work in schools (Пуховська, 2010).

Future technology teachers of European schools are intended to be professionals and highly educated. They really have the most fluent and practical knowledge and skills; they know a large number of teaching methods and approaches. The high educational level of students in many cases allows them to plan their work and choose methods independently. This means that during university training future technology teachers should:

- explore important terminology, materials, and technology; be able to follow the general development of technologies; possess practical skills in their field;

- be familiar with the physical, psychological and social development of both child and adolescent; scientific theories and their application in education, technology education, and the educational process;

- obtain knowledge in the field of technological education and education in general, since it will enable them to learn the basic theory and terminology in this field of education;

- obtain knowledge about society, business sectors, occupations and products, and develop the ability to respond quickly to the situation and changes in society and use the knowledge to solve specific problems. According to the program of technology teacher training, students learn many different technologies, mechanical and electrical engineering, product design, working with research and statistical databases, studying humanities and etiquette, developmental psychology, basis of technological education, management, evaluation and sociology of education (Рогачев, 2000).

5. The scientific approach in the training of future technology teachers. The teacher's activity acquires integral character on modern stage of society development. The integrity of teacher's work is seen in integration of theory and practice.

Our European colleagues think that pedagogic theory helps future technology teachers to learn not only how to explain pedagogical facts and events, but to determine scientifically-based means of work. It is really important for the teacher of modern school to obtain them from scientific sources or during independent analytical work. School pedagogic practice is rich, it constantly brings into the world new facts.

Thus, educational activities of future technology teacher approaches to research, which certainly will allow Ukrainian students to prepare themselves to research work (Пуховська, 2010). 


\section{CONCLUSIONS}

For Europe, the quality of education is a matter of national importance and a prerequisite for social stability. That is why Ukraine (after joining the community of European countries which have signed the Bologna Declaration) acquires urgency to solve the problem of achieving pan-European indicators of quality of training of graduates. Individual and professional competence of teachers of technology depends on many factors, including the educational system where the training is carried out.

Considering the achievements and advanced experience of pedagogical training of future technology teachers in Europe it can be stated that the basis of its international success and the prospects for creative implementation in educational practice in Ukraine are: a) democratization and humanization of future technology teachers training; b) an integrated organization of future technology teachers training; c) a combination of national and traditional approaches to technology teacher training with the internationalization of education; d) practically-oriented nature of future technology teachers training and strengthening relations with school (as a future place of work).

\section{REFERENCES}

1. Marginson, S. (2008). Global field and global imagining: Bourdieu and worldwide higher education. British Journal of Sociology of Education, Volume 29, No. 3, p. 303-315.

2. Valimaa, J. (2004). Nationalisation, localization and globalization in Finnish higher education. Higher Education, No. 48, p. 27-54.

3. Вульфсон, Б. Л. (1999). Стратегия развития образования на Западе на nороге XXI BEKA [Education Development Strategy in the West in the XXI Century]. Москва : Изд-во УРАО, p. 208 (in Russian).

4. Капранова, В. А. (2004). Сравнительная педагогика: Школа и образование за рубежсом [Comparative pedagogy: School and education abroad]. Москва : Новое знание, p. 420 (in Russian).

5. Лахотнюк, Л. А. (2007). Формирование мирового образовательного пространства в условиях глобализации [Formation of world education in the context of globalization]. Вестник ТСГУ. Серия : Педагогика [TSPU Journal. Series: Pedagogy], No. 7 (70), p. 7-10 (in Russian).

6. Пуховська, Л. П. (2010). Професійна підготовка вчителів у краӥнах Західної Свропи: спільність і розбіжності [Teacher training in Western Europe: similarities and differences]. Київ : Вища школа, p. 180 (in Ukrainian).

7. Рогачев, Е. Ю. (2000). Педагогическое образование за рубежсом и альтернативные школы [Pedagogical education abroad and alternative schools]. Москва : Новое издание, p. 212 (in Russian). 